\title{
SOMATIC EMBRYOGENESIS FROM MERISTEM EXPLANTS OF GINGER
}

\author{
OTIH ROSTIANA* AND SITTI FATIMAH SYAHID
}

\author{
*Division of Plant Breeding, Indonesian Medicinal and Aromatic Crops Research Institute \\ Jalan Tentara Pelajar No. 3 Bogor 16111, Indonesia
}

\begin{abstract}
The use of planting materials from in vitro culture, especially derived from somatic embryos has some advantages such as genetically stable and pathogen-free. Meristem culture of ginger through somatic embryogenesis could be a potential method for producing pathogen-free planting materials. Somatic embryogenesis on ginger was performed to obtain vigorous plantlets having the same rhizome size as the mother plant. Callus was induced from meristem tissue of inner bud of Indonesian ginger rhizome Var. Cimanggu-1 and consecutively subcultured into certain media at each steps of experiments. The vigorous embryogenic calli were observed on MS medium containing $100 \mathrm{mgl}^{-1}$ glutamine and $2 \%$ sucrose with addition of $1.0 \mathrm{mgl}^{-1} 2,4-\mathrm{D}+3.0$ $\mathrm{mgl}^{-1} \mathrm{BA}$. The highest number of somatic embryos (about $82.0 . \mathrm{g}^{-1}$ friable calli) was achieved on that medium, 4 weeks after culturing. Furthermore, the optimum growth of embryogenic calli containing somatic embryo was obtained on MS medium enriched with $6 \%$ sucrose. The highest number of mature somatic embryos (57.2 embryos) was achieved on MS medium, 18 days after incubation. The regeneration potency of somatic embryos obtained from ginger meristem was $51.20 \% \cdot \mathrm{g}^{-1}$ friable callus. The valuable result of this study was the achievement of normal rhizome size of regenerated plantlets, instead of micro rhizome.
\end{abstract}

Key words: Zingiber officinale Rosc., meristem culture, somatic embryogenesis.

\section{INTRODUCTION}

Ginger (Zingiber officinale Rosc.) is one of the most important export commodities of Indonesia. This crop is also one of the important components of Indonesian herbal medicine, locally called jamu, phytopharmaca and is contributing to the Indonesian foreign exchange and work opportunity for labors. The lack of market stock and serious damages due to pest and disease, have caused high fluctuations to Indonesian ginger exports and prices within the last decades. To overcome the limiting factors, the use of healthy planting material is necessary to be developed.

Plant tissue culture has been adopted for the purpose of in vitro mass propagation on various crop species. In case of the Big-White Ginger Cultivar of Indonesian Variety Cimanggu-1, the use of shoot bud-derived plantlets, either by direct organogenesis or through callusing, has been developed to obtain disease-free planting materials (Mariska

* Corresponding author : otihrostiana@yahoo.com 
Somatic embryo development of ginger meristem - O. Rostiana \& S.F. Syahid

and Syahid 1994). In further field experiments, the healthy plantlets and vigorous plants were not able to produce normal rhizomes (the same-big rhizome as their mother plants), eventhough they were repeatedly planted in three consecutive generations (Syahid and Hobir 1996). It is suggested that genetic alteration or epigenetic change during the in vitro culture and regeneration have been performed. In order to eliminate the genetic change during the in vitro culture, other regeneration pathway should be considered.

Somatic embryogenesis has been accomplished in some species for producing millions of seeds. The form of somatic seeds through somatic embryogenesis, is more efficient than organogenesis. Besides, somatic embryogenesis is more preferable in plant genetic improvement through in vitro culture and genetic transformation as well, because single cell derived-plant is eassier to be controlled as somatic embryo derived-plant. In general, somatic embryogenesis and meristem derived plants are true-to-type and genetically identical to the mother plants (Evans and Sharp 1986; Jimenez 2001), however, certain differences might appear according to the plant species characteristics. The true-to-type of somatic embryo derived plantlet has been found in in vitro culture of Picea abies (Heinze and Schmidt 1995). On the other hand, among recalcitrant species such as serealia crops and conifers, good results have been performed by the induction of somatic embryogenesis.

Achievements in inducing somatic embryogenesis in monocots are mostly derived from generative explants. Meanwhile, in dicotyl vegetative explant, such as leaves, are commonly applied for inducing somatic embryo derived-plantlet. Leaf explant of orchard grass completely induces somatic embryo through the formation of embryogenic calli with addition of a strong auxin like dicamba (Bhojwani and Razdan 1996). On the other hand, Kackar et al. (1993) performed the somatic embryo culture of Indian ginger Var. Eruttupetta by using an aseptic leaf-explant with the addition of 2,4-D and dicamba. The same explant source was also performed in inducing somatic embryogenesis of fingerroot (Boesenbergia rotunda L.) and galangal (Kaempferia galanga L.) (Tan et al. 2005; Rahman et al. 2004).

This study was aimed at obtaining the normal-size of rhizome (the same size as their mother plant) through induction of somatic embryos from meristem explant of Indonesian Var. Cimanggu-1. Most meristematic cells of meristem tissue derivedsomatic embryo are genetically stable and not easy to be mutated (Bach and Pawlowska 2003). Therefore, to eliminate somaclonal variation and other genetic alteration during the in vitro culture, meristem tissue will be applied for the induction of somatic embryogenesis on ginger. 


\section{MATERIALS AND METHODS}

\section{Explant preparation}

The inner shoot bud (meristem) of Indonesian Var. Cimanggu-1, was excised and simultaneously sterilised by using sterilizing agents such as $70 \% \mathrm{EtOH}, 5 \%$ sodium hypochlorite and $0.2 \%$ mercury chloride, for about 5-10 minutes, followed by rinsing with sterile-aquadest.

\section{Callus induction}

Sterilized meristems were placed on MS basal medium (Murashige and Skoog 1962) consisting of $8 \%$ agar, $2 \%$ sucrose, $100 \mathrm{mg} \mathrm{l}^{-1} \mathrm{~L}$-glutamine, 1.0 to $3.0 \mathrm{mg} \mathrm{l}^{-1}$ 2,4-dichlorophenoxy acetic acid (2,4-D) and 0 to $5.0 \mathrm{mg} \mathrm{l}^{-1} \mathrm{~N}^{6}$-benzyl adenin (BA). A single factor experiments were arranged in completely randomized design, replicated three times.

\section{Subculturing.}

Embryogenic calli were formed 8 weeks after culturing on callus induction medium, and then transferred on to hormone-free MS or $\mathrm{N}_{6}$ basal media with the addition of $3 \%$ mannitol for calli proliferation. A single factor experiments were arranged in completely randomized design, replicated four times for each treatments.

Pro-embryos were then subcultured into the best basal medium, either MS or $\mathrm{N}_{6}$ basal media, according to the best result of the previous stage of experiment, with the addition of $6 \%$ sucrose $(6 \mathrm{~S})$ for obtaining mature embryo. Single-factor experiments were arranged in completely randomized design, replicated four times.

\section{Regeneration}

Mature embryos (torpedo-like structure-embryos) were subcultured into regeneration medium for further development. MS basal medium with addition of 3\% sucrose and $200 \mathrm{mgl}^{-1} \mathrm{~L}$-proline were applied in combination with PGRs such as BA at the concentration of $0,0.1,0.5$ and $1.0 \mathrm{mgl}^{-1}, \mathrm{GA}_{3}$ at the concentration of $0,0.1,0.3$, 0.5 and $1.0 \mathrm{mgl}^{-1}$. Single-factor experiments were arranged in completely randomized design, replicate three times.

\section{Histology}

The callus at each stage of development was subjected to histological analysis according to Sass (1951) by using paraffin-embedded callus dissection following Formaldehyde-glacial Acetic acid-Alcohol (FAA) fixation series.

\section{Statistical analysis}

All collected data were analyzed by using ANOVA $\left(\mathrm{P}_{0.05}\right)$ followed by Duncan's Multiple Range Test (P. 0.05) (Windows Computers, 2000). Observation results on embryo proliferation were analyzed by using t-test according to Furlong et al. (2000). 


\section{RESULTS AND DISCUSSION}

\section{Callus induction}

Callus initiation was on tract when the basal-edge of the meristems enlarged, followed by the change of shoot-dome colour from white to yellowish, at two weeks after culturing. Eight weeks after culturing, friable callus (embryogenic callus) formation of about 93.33\%/explant was formed on MS basal medium enriched with $1 \mathrm{mg}^{1-1} 2,4-\mathrm{D}$ in combination with $3 \mathrm{mg} \mathrm{l}^{-1} \mathrm{BA}$. Though, that combination was statistically the same as the treatment without BA (Table 1).

Table 1. Percentage of embryogenic calli from ginger meristem cultured on MS medium enriched with various concentration of 2,4-D and BA, 8 weeks after culturing

\begin{tabular}{cccc}
\hline & Treatment & & \\
\hline \multirow{2}{*}{$2,4-\mathrm{D}\left(\mathrm{mg} \cdot \mathrm{L}^{-1}\right)$} & Percentage of embryogenic calli (\%) \\
\hline 1 & BA $\left(\mathrm{mg} \cdot \mathrm{L}^{-1}\right)$ & 86.67 & \\
\hline & 0 & 8.33 & $\left.\mathrm{a}^{*}\right)$ \\
& 1.0 & 93.33 & $\mathrm{a}$ \\
& 3.0 & 70.00 & $\mathrm{~b}$ \\
& 5.0 & 46.67 & $\mathrm{c}$ \\
& 0 & 25.00 & $\mathrm{~d}$ \\
& 1.0 & 63.33 & $\mathrm{~b}$ \\
& 3.0 & 61.67 & $\mathrm{~b}$ \\
& 5.0 & 28.33 & $\mathrm{~d}$ \\
& 0 & 36.67 & $\mathrm{~cd}$ \\
& 1.0 & 63.33 & $\mathrm{~b}$ \\
& 3.0 & 61.67 & $\mathrm{~b}$ \\
\hline
\end{tabular}

Note:

Numbers followed by the same letters are not significantly different according to DMRT (5\%).

The application of 2,4-D on ginger meristem culture showed that the higher the concentration applied, the more compact calli were observed. Furthermore, when 2,4-D was applied at 2-3 mg..$^{-1}$ browning and necrotic calli were observed. An addition of $1.0 \mathrm{mg} \cdot \mathrm{l}^{-1} \mathrm{BA}$ into medium containing $2,4-\mathrm{D}$ neither vigorous embryogenic calli were obtained, low quantity and compact calli were observed (Table 1).

\section{Embryogenesis from the subcultured callus}

For obtaining globular somatic embryos structure the formed embryogenic calli were cultured on either MS or $\mathrm{N}_{6}$ basal media with the addition of 3\% mannitol. Transparent globular embryos were developed on both media in one week after subculturing. The shape of ginger embryos at globular phase was generally round or oval (Fig. 1a). 


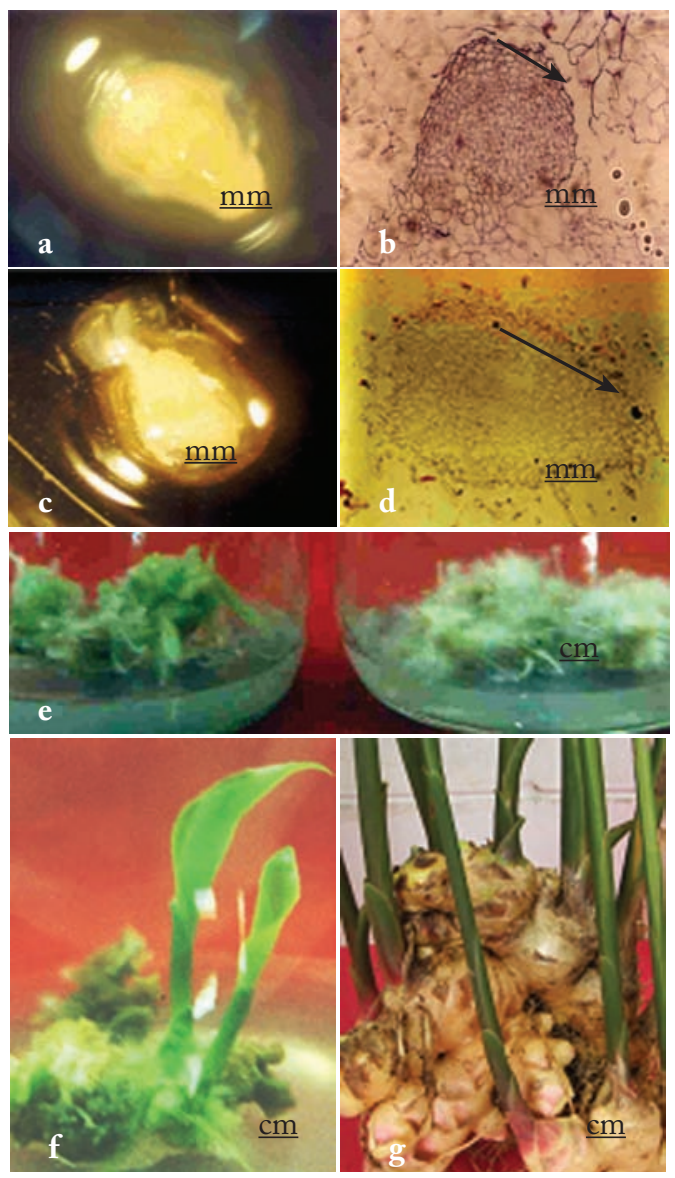

Figure 1. The development of ginger meristem into newly regenerated plant with normal rhizome size through somatic embryogenesis.

a. The structure of globular somatic embryo of ginger, 4 weeks after subculturing into proliferation medium (30 times enlargement).

b. Globular embryo, 2 weeks after proliferation (40 times enlargement). Protoderm layer started to differentiate (arrowed).

c. The structure of torpedo somatic embryo of ginger, 18 days after subculturing into maturation medium (10 times enlargement).

d. Torpedo embryo, 18 days after subculturing into maturation medium (40 times enlargement). Arrowed: differentiated procambium.

e. Embryo somatic-derived seedlings on MS medium supplemented with $1 \mathrm{mgl}^{-1} \mathrm{BA}$ (Left) and embryo somatic-forming adventitious roots on hormone free-MS medium (Right), 30 days after subcultured ( $1: 1.4$ scaled).

f. Embryo somatic-derived normal plantlet, 8 weeks after subcultured on to hormone-free MS medium (1: 1.3 scaled).

g. Normal rhizome size of ginger-regenerated plants obtained from meristem culture through somatic embryogenesis. 
Somatic embryo development of ginger meristem - O. Rostiana \& S.F. Syahid

Numbers of globular phase of somatic embryos increased due to the age of cultures. The highest number of somatic embryo was obtained at 4 weeks after

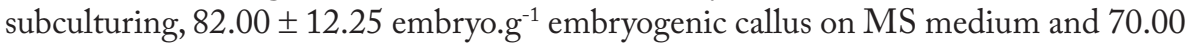
\pm 19.26 embryo. ${ }^{-1}$ embryogenic callus on $\mathrm{N}_{6}$ medium. Statistical analysis showed that MS basal medium was more capable in inducing higher numbers of somatic embryo than that of $\mathrm{N}_{6}$ basal medium $\left(\mathrm{P}_{0.05}\right)$. The number of somatic embryo decreased by the increase of age of cultures (Table 2). Histological analysis conformed that the somatic embryo was induced from cortex tissue and that the globular phase developed at 2 weeks after culturing on proliferation medium (Fig. 1b).

Table 2. Number of somatic embryos derived from ginger meristem culture on MS and $\mathrm{N}_{6}$ basal media enriched with $3 \%$ mannitol

\begin{tabular}{ccc}
\hline \multirow{2}{*}{ Period (weeks) } & \multicolumn{2}{c}{ Average number of somatic embryos/g of embryogenic callus } \\
\cline { 2 - 3 } & MS & $\mathrm{N}_{6}$ \\
\hline 1 & $32.75 \pm 11.97$ & $39.75 \pm 5.31$ \\
3 & $54.50 \pm 20.16$ & $51.50 \pm 9.66$ \\
4 & $70.50 \pm 31.97$ & $48.75 \pm 15.16$ \\
5 & $82.00 \pm 12.25^{1)}$ & $70.00 \pm 19.26^{1)}$ \\
6 & $53.75 \pm 16.32$ & $36.25 \pm 9.28$ \\
7 & $51.50 \pm 10.92$ & $22.75 \pm 15.28$ \\
\hline
\end{tabular}

Note: Based on t-test at $5 \%$ level.

Mature embryo formation was performed on MS basal medium, enriched with $6 \%$ sucrose. Cylindrical form of mature embryo started to develop into 2 different domes, i.e. cotyledons and apical shoot-forming dome as well as root-forming dome. Two days after subculturing into MS medium enriched with 6\% sucrose, about 10.60 \pm 4.76 torpedo-shape somatic embryos were initiated from $1 \mathrm{~g}$ of embryogenic calli (Table 3). 
BIOTROPIA VOL.15 NO. 1, 2008

Table 3. Number of mature somatic embryos on MS basal medium supplemented with $6 \%$ sucrose

\begin{tabular}{cc}
\hline Age(day) & Average number of mature embryo/g of embriogenic calli ${ }^{1)}$ \\
\hline 2 & $10.60 \pm 4.76$ \\
6 & $33.40 \pm 6.74$ \\
10 & $55.80 \pm 12.73$ \\
14 & $38.60 \pm 6.53$ \\
18 & $57.20 \pm 15.99$ \\
22 & $45.80 \pm 10.50$ \\
26 & $28.00 \pm 8.65$ \\
30 & $16.20 \pm 8.91$ \\
\hline
\end{tabular}

The highest number of torpedo-shape somatic embryo (57.20 \pm 15.99 embryos) was obtained at 18 days after subculturing. Mature somatic embryo was capable to form two different domes, i.e. shoot and root (Fig. 1c-d). However, in some cases apical meristem structure was more dominant than shoot meristem.

Histological section showed that during the formation of torpedo-shape somatic embryo, root-apical, procambium and scutellum differentiations were performed (Fig. $1 \mathrm{c}-\mathrm{d})$.

\section{Regeneration}

Germination of somatic embryo was characterized by the formation of the triangle-shape at meristem apical dome with yellow greenish in color, at 6 days after subcultured. At the second week of culturing, germinating seeds started to appear and developed to become normal seedlings/plantlets, especially when BA was added into MS basal medium.

Three weeks after culturing, various shapes of somatic embryos either a single normal or fused embryos, had been differentiated into plantlets. Meanwhile, the abnormal embryos underwent necrosis and then aborted. Embryo germination was indicated by the presence of shoot and root buds. Four weeks after culturing, the morphogenesis of somatic embryos were clearly visible, nevertheless the low ability of somatic embryos to germinate was still a limiting factor in meristem culture of ginger.

MS basal medium supplemented with $1 \mathrm{mgl}^{-1} \mathrm{BA}$ was found to be the best culture medium for obtaining normal plantlets at the age of 30 days, to which the highest number of seedlings was obtained (22.1 seedlings). On the other hand, instead of growing plantlet, vigorous adventitious roots were obtained on hormone-free MS medium (Fig. 1e). Furthermore, it was found that both BA and GA significantly affected the somatic embryo regeneration $\left(\mathrm{P}_{0.05}\right)$. However, the higher the concentration of $\mathrm{GA}_{3}$, the lower the number of seedlings was obtained (Table 4). 
Somatic embryo development of ginger meristem - O. Rostiana \& S.F. Syahid

Table 4. Number of seedlings derived from somatic embryo of ginger meristem cultured on MS medium supplemented with $\mathrm{BA}$ and $\mathrm{GA}_{3}$

\begin{tabular}{ccc}
\hline & Treatment & \\
\hline \multirow{2}{*}{$\mathrm{BA}\left(\mathrm{mgl}^{-1}\right)$} & $\mathrm{GA}_{3}\left(\mathrm{mgl}^{-1}\right)$ & \\
\hline 0 & 0 & Average number of seedlings \\
& 0.1 & $7.3 \mathrm{~cd}$ \\
& 0.3 & $16.4 \mathrm{ab}$ \\
& 0.5 & $16.4 \mathrm{ab}$ \\
& 1.0 & $9.3 \mathrm{bcd}$ \\
0.1 & 0 & $9.3 \mathrm{bcd}$ \\
& 0.1 & $7.3 \mathrm{~cd}$ \\
& 0.3 & $10.0 \mathrm{bcd}$ \\
& 0.5 & $3.7 \mathrm{de}$ \\
0.5 & 1.0 & $16.1 \mathrm{ab}$ \\
& 0 & $11.5 \mathrm{bc}$ \\
& 0.1 & $0.5 \mathrm{f}$ \\
& 0.3 & $0.5 \mathrm{f}$ \\
1 & 0.5 & $0.5 \mathrm{f}$ \\
& 1.0 & $12.8 \mathrm{abc}$ \\
& 0 & $17.4 \mathrm{ab}$ \\
& 0.1 & $22.1 \mathrm{a}$ \\
& 0.3 & $12.6 \mathrm{abc}$ \\
& 0.5 & $0.5 \mathrm{abc}$ \\
1.0 & $1.2 \mathrm{ef}$ \\
\hline
\end{tabular}

Notes: Numbers followed by the same letter are not significantly different according to DMRT (5\%). For statistical analysis data were transformed into $\sqrt{ }(y+0.5)$.

Based on this study, it was found that regeneration potency of meristem culture of ginger through somatic embryogenesis was $51.20 \% \mathrm{~g}^{-1}$ of embryogenic calli when cultured on MS medium supplemented with $1 \mathrm{mg} \mathrm{l}^{-1} \mathrm{BA}$. The addition of $\mathrm{GA}_{3}$ into $\mathrm{MS}$ basal medium produced only $34.13 \%$ of regeneration potency, and 1.13 to $31.84 \%$ of regeneration potency when $\mathrm{BA}$ was combined with $\mathrm{GA}_{3}$. Therefore, to gain an optimal germination of ginger somatic embryo, higher concentration of $\mathrm{BA}\left(\geq 1 \mathrm{mg} \cdot \mathrm{l}^{-1}\right)$ without addition of $\mathrm{GA}_{3}$, was necessary.

Germinating somatic embryos from MS medium supplemented with either 1 $\mathrm{mg} \mathrm{l}^{-1} \mathrm{BA}, 0.5 \mathrm{mg} \mathrm{l}^{-1} \mathrm{BA}, 0.1 \mathrm{mg} \mathrm{l}^{-1} \mathrm{BA}+0.3 \mathrm{mg} \mathrm{l}^{-1} \mathrm{GA}_{3}$ or $0.1 \mathrm{mg} \mathrm{l}^{-1} \mathrm{GA}_{3}$ were then transferred onto hormone-free MS medium with the addition of $3 \%$ sucrose. Among them, the most vigorous plantlets were obtained from $\mathrm{MS}+0.1 \mathrm{mg} \mathrm{l}^{-1} \mathrm{BA}+0.3$ $\mathrm{mg}^{1-1} \mathrm{GA}_{3}$ culture medium-derived seedlings (Fig. 1f), at 8 weeks after subculturing. However, the number of embryo somatic-generated plantlets remained low, of which only about 2-6 plantlets were observed. 
Abundant embryogenic calli (93.33\%/explant) from meristem culture of ginger were achieved on MS basal medium supplemented with $1 \mathrm{mg} \mathrm{l}^{-1} 2,4-\mathrm{D}$ in combination with $3 \mathrm{mg} \mathrm{l}^{-1} \mathrm{BA}$, and $100 \mathrm{mg} \mathrm{l}^{-1} \mathrm{~L}$-glutamine, at 8 weeks after incubation. This result showed that 2,4-D was necessary for initiation of embryogenic callus of ginger, with the addition of BA at proper concentration. The same result was also found in embryogenic callus initiation of Kaempferia galanga L. (Vincent et al. 1992).

Callus proliferations were obtained on hormone-free MS medium consisting of 3\% mannitol. A globular-shape pro-embryo started to develop at the first week after subculturing into proliferation medium. Quantities of globular embryo increased due to the age of culturing up to seven weeks, then gradually decreased.

Ammonium-rich basal media such as MS, which consists of high concentration of $\mathrm{NH}_{4} \mathrm{NO}_{3}$ and myo-inositol, supported well the differentiation of ginger somatic embryo, though an adverse effect was observed on other Grammineae species (Talwar and Rashid 1989; Adkins et al. 2002). Salt nutrients in MS medium with addition of 3 to $12 \%$ sucrose are usually sufficient to support embryo differentiation (Raghavan 2003; Anbazhagan and Ganapathi 1999). An addition of 3\% mannitol into MS basal medium, assumed that it acted as an osmotic regulator which in turn affected the rate of cell differentiation and stimulated embryogenic cells morphogenesis in meristem culture of ginger. Torres et al. (2001) reported that the development of synchronized embryo and the increase of its quantity were observed when mannitol was added into MS medium. The same results were also found on embryogenic culture of papaya, celery, alfalfa and maize (Ziv 1999; Bronsema et al. 1997).

Somatic embryo maturation in meristem culture of ginger was indicated by the change of embryo color and formation of the brown spots. These brown spots suggest the presence of an active substance i.e. amylum, protein and lipid, secreted by somatic embryo from the osmotic cell pressure. The increase of secretion of active substances suggests its correlation with the desiccation process when somatic embryo enters the germination phase. Bach and Pawlowska (2003) suggested that the presence of amylum, protein and lipid around the vascular cells was an indicator in somatic embryo development. Similarly, Oropeza et al. (2001) reported that the development of embryogenic calli was associated with the number and type of intracellular protein and callus cells. Hence, somatic embryo maturation from proliferated calli of ginger meristem is interrelated with the type and number of active substance among the embryogenic cells.

The growth and development of ginger mature somatic embryo into complete plantlets (seedlings) sometimes go along with the abnormal germinated seeds, such unexpected growth of hairy roots, hereafter we named as an early germinating seeds. According to Bronsema et al. (1997), somatic embryo maturation is associated with the presence of scutellum, a coleoptile and root-bud like structures. Somatic embryo maturation was also affected by the composition of applied culture medium. The presence of ammonium ion and nitrate at a high concentration is a prerequisite in ginger somatic embryo development. High concentration of ammonium ion supported the process of 
somatic embryo differentiation into normal plantlets (George 1993). These results were in agreement with the findings of Krikorian (1995), Adkins et al. (2002) and Ramage and Williams (2002). However, the needs of ammonium ion for the growth of somatic embryo and its morphogenesis depend on the explant sources and the initial plant growth regulators applied.

According to Percy et al. (2000), high osmotic pressure in culture medium would increase the somatic embryo formation. Sucrose, usually applied as a carbon source, is also a potent osmotic agent (van Creij et al. 1999). Another potential osmotic agent is Abscisic Acid (ABA), that at a proper concentration it would enable to control the medium osmolarity (Raghavan 2003; Mohan and Krishnamurthy 2002). To overcome the early seeds germination (the formation of unexpected hairy roots) in somatic embryogenesis of ginger, an experiment on addition of $\mathrm{ABA}$, aside from sucrose, into culture medium of somatic embryo maturation is now in progress.

Somatic embryo germination was indicated by the simultaneous formation of shoots and roots. Goh et al. (1999) stated that embryo germinated when the plumullae started to emerge. In this research, adventitious roots formation was observed at first stage of regeneration and increased by the increase of age of culture up to the fourth week.

Addition of plant growth regulators into regeneration medium would accelerate the germination process and increase the quantity and quality of seedlings. In this research, a high percentage of somatic embryo germination was observed on the medium containing $1 \mathrm{mg} \cdot \mathrm{l}^{-1} \mathrm{BA}$, at 30 days after culturing. Regeneration potency of ginger meristem somatic embryo reached $51.20 \% \cdot \mathrm{g}^{-1}$ of embryogenic calli cultured on MS basal medium enriched with $1 \mathrm{mgl}^{-1} \mathrm{BA}$, of which the number of seedlings was 8.98 times higher than that of the control medium. Meanwhile, $\mathrm{GA}_{3}$ alone or in combination with BA, remained ineffective in supporting somatic embryo germination of ginger. However, to obtain the optimum growth of plantlet, the presence of BA is a prerequisite in meristem culture derived somatic embryo of ginger. Similar result was also found in the development of ginger leaf derived embryogenic callus (Kackar et al. 1993), though simultaneous development of somatic embryo derived either root or shoot meristems remained unclear.

The development of somatic embryo into normal plantlet commonly occurs through four stages i.e. callus induction, callus proliferation, embryo maturation and germination. In case of somatic embryo derived from ginger meristem culture, its development into normal plantlet needs a transfer process of germinated seeds from the regeneration medium into new medium. Such new medium is called growth medium for plantlet development. In this experiment the medium used for the growth of plantlet was hormone-free MS medium with the addition of $3 \%$ sucrose.

Although the development of protocol in ginger somatic embryogenesis required more researches, the results of this experiment, somehow, have a definite advantage in in vitro studies of ginger, especially in generating healthy planting material with normal rhizome size, a bigger size than the usual micro rhizomes resulted from shoot 
tip-derived in vitro plantlets (Fig. $1 \mathrm{~g}$ ). Therefore, the encouraging results of this study gave great possibility for development of ginger resistant variety either through in vitro selection, somatic hybridization or genetic transformation.

\section{CONCLUSIONS}

The addition of $1 \mathrm{mg} \cdot \mathrm{l}^{-1} 2,4-\mathrm{D}$ and $3 \mathrm{mg} \cdot \mathrm{1}^{-1} \mathrm{BA}$ into $\mathrm{MS}$ basal medium enriched with $100 \mathrm{mg} \cdot .^{-1}$ of glutamine and $2 \%$ sucrose, was effective in inducing embryogenic calli from meristem explants of Indonesian ginger. In further embryo development, MS medium was found to be more capable to increase mature somatic embryo than $\mathrm{N}_{6}$ medium.

The regeneration potency of somatic embryos obtained from Indonesian ginger meristem was $51.20 \% / \mathrm{g}$ friable callus. Though, further researches are needed to be conducted, especially to eliminate early germinating seeds. The protocol for generating somatic embryo derived plantlet from meristem culture of ginger was developed. The most valuable result of this study was the achievement of normal rhizome size of regenerated plantlet, instead of micro rhizome.

\section{ACKNOWLEDGEMENT}

The authors would like to thank Dr. Ika Mariska for her assistance and encouragement during the research work and the manuscript preparation and also to Dr. D. Sitepu for his critical reading of the manuscript, and Ms. R.R. Sitinjak for her contribution on the research work.

\section{REFERENCES}

Adkins, S.W., A.L.Adkins, C.M. Ramage and R.R.Williams. 2002. In vitro ecology: Modification of headspace and medium conditions can optimize tissue and plant development. In: Taji A, R. Williams (eds) The importance of plant tissue culture and biotechnology in plant sciences. University of New England Unit, Australia, pp. 55-77.

Anbazhagan V.R. and A. Ganapathi. 1999. Somatic embryogenesis in cell suspension cultures of pigeon pea (Cajanus cajan). Plant Cell, Tissue Organ Cult. 56: 179-184.

Bach, A and B. Pawlowska. 2003. Somatic embryogenesis in Gentiana pneumonanthe L. Acta Bio. Crac. Series Bot. 45 (2): 79-86.

Bhojwani, S.S. and M. Razdan. 1996. Plant tissue culture: Theory and practice. Elsevier Amsterdam, Oxford, New York, Tokyo. 
Somatic embryo development of ginger meristem - O. Rostiana \& S.F. Syahid

Bronsema, F.B.F., W.J.E. van Oostveen and A.A.M.van Lammeren. 1997. Comparative analysis of callus formation and regeneration on cultured immature maize embryos of the inbred lines A188 and A632. Plant Cell, Tissue Organ Cult. 50: 57-65.

Evans, D.E and W.R. Sharp. 1986. Somaclonal and gametoclonal variation. In: Evans et al. (eds) Hand book of plant cell culture, Vol. 4, Technique and application. MacMillan Pub. Co., New York, pp. 97-132.

Furlong, N.E., E.A, Lovelace and K.L. Lovelace. 2000. Research methods and statistics an integrated approach. Harcourt College, Tokyo.

George, E.F. 1993. Plant propagation by tissue culture. $2^{\text {nd }}$ ed. Exegetics Ltd, England.

Goh, D.K.S., N. Michaux-ferriere, O. Monteuuis and M.C. Bon. 1999. Evidence of somatic embryogenesis from root tip explants of the rattan Calamus manan. In Vitro Cell. Dev. Biol. Plant. 35: 424-427.

Heinze, B and J. Schmidt. 1995. Monitoring genetic fidelity vs somaclonal variation in Norway spruce (Picea abies) somatic embryogenesis by RAPD analysis. Euphytica 85: 341345 .

Jimenez, V.M. 2001. Regulation of in vitro somatic embryogenesis with emphasis on the role of endogenous hormones. R. Bras. Fisiol. Veg. 13 (2): 196-223.

Kackar, A., S.R. Baht, K.P.S. Chandel and S.K. Malik. 1993. Plant regeneration via somatic embryogenesis in ginger. Plant Cell. Tissue Organ Cult. 32: 289-292.

Krikorian, A.D. 1995. Hormones in tissue culture and micropropagation. In: P.J. Davies (ed.) Plant hormones: Physiology, biochemistry and molecular biology. Kluwer Academic, Dordrecht, Boston, London, pp. 774-793.

Mariska, I and S.F. Syahid. 1994. Propagation of ginger through meristem culture. J. Indust. Crops. Res. 7 (1): 1-6.

Murashige, T and F. Skoog. 1962. A revised medium for rapid growth and bio assays with tobacco tissue cultures. Physiol. Plant. 15: 473-497.

Mohan, M.L and K.V. Krishnamurthy. 2002. Somatic embryogenesis and plant regeneration in pigeon pea. Biol. Plant. 45 (1): 19-25.

Oropeza, M., A.K. Marcano and E. De Garcia. 2001. Proteins related with embryogenic potential in callus and cell suspensions of sugarcane (Saccharum sp.). In Vitro Cell Dev. Biol. Plant. 37: 211-216.

Percy, R.E., K. Klimaszewska and D.R. Cyr. 2000. Evaluation of somatic embryogenesis for clonal propagation of western white pine. Can. J. For. Res. 30: 1867-1876.

Raghavan, V. 2003. One hundred years of zygotic embryo culture investigations. In Vitro Cell. Dev. Biol. Plant. 89: 437-442.

Rahman, N.N.,M.N. Amin, T. Ahamed, M.R. Ali and A. Habib. 2004. Efficient plant regeneration through somatic embryogenesis from leaf base-derived callus of Kaempferia galanga L. Asian J. Plant Sci. 3 (6): 675-678.

Ramage, C.M and R.R. Williams. 2002. Mineral nutrition and plant morphogenesis. In Vitro Cell. Dev. Biol. Plant. 38: 116-124.

Sass, J.E. 1951. Botanical microtechnique. Iowa State University Press, Ames. 
BIOTROPIA VOL. 15 NO. 1, 2008

Syahid, S.F and Hobir. 1996. The growth and rhizome yield of ginger derived from in vitro culture. J. Indust. Crops. Res. 2 (2): 95-100.

Talwar, M and A. Rashid. 1989. Somatic embryo formation from unmerged inflorescences and immature embryos of a graminaceous crop echinochloa. Ann. Bot. 64: 195-199.

Tan, S.K., R. Pippen, R. Yusof, H. Ibrahim, N. Rahman and N. Khalid. 2005. Simple one-medium formulation regeneration of fingerroot [Boesenbergia rotunda (L.) Mansf. Kulturfl.] via somatic embryogenesis. In Vitro Cell Dev. Biol. Plant 41: 757-761.

Torres, A.C., N. Mfëe-Ze and D.J. Cantliffe. 2001. Abscisic acid and osmotic induction of synchronous somatic embryo development of sweet potato. In Vitro Cell. Dev. Biol. Plant. 37: 262-267.

Van Creij, M.G.M., D.M.F. Kerckhoffs, S.M. De Bruijn, D. Vreugdenhil and J.M. Van Tuyl. 1999. The effect of medium composition on ovary-slice culture and ovule culture in intraspecific Tulipa gesneriana L. crosses. Available at <http://www.liliumbreeding.ne/crey-med.htm>[12/06/04].

Vincent, K.A., M. Hariharan and K.M. Mathew. 1992. Embryogenesis and plantlet formation in tissue culture of Kaempferia galanga L. a medicinal plant. Phytomorphology. 42 (3 \& 4): 253-256.

Ziv, M. 1999, Developmental and structural patterns of in vitro plants. In: Soh W, Bhojwani SS (ed.) Morphogenesis in plant tissue culture. Kluwer Academic, Dordrecht, Boston, London, pp. 235-253. 